\title{
Dinamika Pengakuan Penghayat Kepercayaan di Indonesia
}

Indonesian Journal of Religion and Society, 2020, Vol. 02 (02), 97-112

(C) The Journal, 2020

DOI: $10.36256 /$ ijrs.v2i2.119

$\underline{\text { www.journal.lasigo.org/index.php/IJRS }}$

acher

Journal

Article History

Received:November, $11^{\text {th }} 2020$

Revised: December, 23rd 2020

Accepted: December, 24th 2020

\section{Kristina Viri}

Magister Hukum, Universitas Gadjah Mada, Yogyakarta, Indonesia

kristinaviri@mail.ugm.ac.id

\section{Zarida Febriany}

Magister Hukum, Universitas Gadjah Mada, Yogyakarta, Indonesia zarida.febriany@mail.ugm.ac.id

\begin{abstract}
Indonesia has various local religions that live a hundred years, even before independence. These religions are known as "Penghayat Kepercayaan". In history, the adherents of these beliefs experienced hardship dynamics to gain recognition from the State. The methodology that has been used for this research is a normative juridical or documentary study with qualitative analysis. The result and discussions of this research concluded that Article $28 E$ of the 1945's Constitution guaranteed everyone to have the right of freedom to believe. However, the reality is the opposite as the State is discriminating between the officials and the unofficial religions. Because of the long struggles of the stakeholders, the community of Penghayat Kepercayaan has pleaded to the Constitutional Court (MK) for a judicial review, and it was accepted. MK has stated that discrimination between the official and the unofficial religions is a contradiction to the 1945's Constitution. Based on the decision of MK, the State recognizes the community of Penghayat Kepercayaan, especially for all the matters related to their rights for civil administration (where now, there is a "belief" column for them, in the Family Card and electronic ID), and their rights to embrace and worship.
\end{abstract}

Keywords: Penghayat Kepercayaan, State Recognition, Discrimination, Rights of Belief

\begin{abstract}
ABSTRAK
Indonesia memiliki keberagaman agama lokal yang telah hidup ratusan tahun sebelum merdeka. Saat ini, agama lokal dikenal sebagai penghayat kepercayaan. Dalam sejarahnya, penghayat kepercayaan tersebut mengalami dinamika dan pasang surut untuk mendapatkan pengakuan dari Negara. Penelitian ini dilakukan secara yuridis normatif atau studi dokumenter dengan analisis kualitatif. Kesimpulan dari hasil dan diskusi penelitian ini adalah bahwa Pasal 28E UUD 1945 telah menjamin setiap orang berhak atas kebebasan meyakini kepercayaan. Namun kenyataannya, negara masih membedakan agama resmi dan tidak resmi. Berkat perjuangan panjang berbagai stakeholder, kelompok penghayat kepercayaan mengajukan permohonan judicial review ke Mahkamah Konstitusi (MK) dan dikabulkan. MK menyatakan pembedaan antara agama yang diakui (agama resmi) dan agama yang tidak diakui (agama tidak resmi-termasuk kepercayaan) dinyatakan bertentangan dengan Undang Undang Dasar 1945. Mengacu pada putusan MK, negara memberikan pengakuan kepada para penghayat kepercayaan, terutama berkaitan dengan administrasi kependudukan (Kartu Keluarga (KK) dan KTP Elektornik yang telah mencantumkan kolom "kepercayaan") serta hak memeluk dan menjalankan ibadah.
\end{abstract}

Kata Kunci: Penghayat Kepercayaan, Pengakuan Negara, Diskriminasi, Hak Keperayaan. 


\section{Pendahuluan}

Bhinneka Tunggal Ika adalah semangat dan jiwa keberagaman di Indonesia. Salah satu wujud keberagaman di Indonesia adalah adanya berbagai agama lokal yang telah lahir ratusan tahun sebelum Indonesia Merdeka. Agama-agama tersebut misalnya Sunda Wiwitan di Jawa Barat, Sedulur Sikep di Jawa Tengah, Kaharingan di Kalimantan, Ugamo Batak di Sumatera Utara dan masih banyak lagi. Saat ini agama lokal dikenal dengan istilah kepercayaan berdasarkan Undang-Undang Nomor 23 Tahun 2006 Tentang Administrasi Kependudukan. Istilah ini juga merupakan bagian dari hasil perjuangan panjang berbagai kelompok penghayat kepercayaan di Indonesia untuk mendapatkan pengakuan dari Negara (Viri, 2008). Untuk mendapatkan pengakuan Negara, berbagai upaya dilakukan oleh penghayat kepercayaan. Salah satu yang berhasil adalah mengajukan uji materi UndangUndang Nomor 23 Tahun 2006 Tentang Administrasi Kependudukan. Uji materi ini dikabulkan oleh Mahkamah Konstitusi, dimana saat ini penghayat kepercayaan dapat memiliki Kartu Tanda Penduduk (KTP) yang menyebutkan sebagai penghayat kepercayaan. Sebelum Uji Materi ini penghayat kepercayaan dapat memiliki Kartu Tanda Penduduk (KTP), namun di kolom agama tertulis (-). Hal ini mendorong diskriminasi untuk pelayanan lainnya. Karena kosong seringkali penghayat dianggap tidak beragama, ateis dan dipersulit mengkases layanan lainnya.

Keberhasilan ini merupakan bagian dari sejarah perjuangan panjang penghayat kepercayaan untuk mendapat pengakuan dari Negara. Dari masa penyusunan naskah Undang-Undang Dasar Negara Republik Indonesia Tahun 1945 (selanjutnya disebut UUD 1945), penghayat kepercayaan telah ikut berjuang untuk menuju kemerdekaan serta memperjuangkan pengakuan. Hal ini dapat dilihat dalam risalah pembahasan UUD 1945 dimana Wongsonegoro memperjuangkan masuknya kata "kepercayaan" dalam Pasal 29 UUD 1945 (Abidin et al., 2019). Perjuangan terus berlanjut sampai pada masa setelah reformasi, kelompok penghayat juga mengawal pembahasan-pengesahan Undang-Undang Nomor 23 Tahun 2006 Tentang Administrasi Kependudukan, walaupun hasilnya sejumlah pasal masih mendiskriminasi penghayat kepercayaan (Mahkamah Konstitusi, 2016).

Berbagai bentuk diskriminasi dan kekerasan oleh negara telah dialami oleh penghayat kepercayaan (Viri, 2008). Salah satu puncak kekerasan terjadi pada tahun 1965, dimana setelah terjadi peristiwa yang biasa dikenal sebagai G30SPKI, berbagai kelompok penghayat di berbagai daerah dipaksa masuk dan memilih salah satu dari 5 (lima) agama "resmi" di Indonesia. Jika tidak, kelompok penghayat akan rentan digolongkan sebagai kelompok komunis/pendukung Partai Komunis Indonesia. Hal ini terjadi setidaknya kepada pemeluk Kawruh Naluri/KWN di Banyumas Jawa Tengah yang akhirnya karena dipaksa, sebagian mereka memilih agama Budha dan sabagian lainnya Kristen (Abidin et al., 2019). Ini juga terjadi pada komunitas Mollo yang akhirnya memilih agama Kristen (Maarif, 2019).

Setelah peristiwa tersebut, pemerintah dan DPR mengesahkan Undang Undang Nomor 1 PNPS 1965 tentang Pencegahan Penyalahgunaan dan/atau Penodaan Agama. Dengan adanya Undang-Undang ini seolah-olah menjadi dasar legitimasi bahwa agama yang diakui di Indonesia hanya 5 (lima) yaitu: Islam, Kristen, Katolik, Hindu, dan Budha. Bagaimana dengan penghayat kepercayaan? Menurut Undang-Undang ini, menjadi kelompok penghayat adalah berbahaya, mengancam dan menodai agama. Hal ini sebagaimana ditulis dalam penjelasan nomor 2 yang berisi: "Telah teryata, bahwa pada akhir-akhir ini hampir di seluruh Indonesia tidak sedikit timbul aliran-aliran atau Organisasi-organisasi kebatinan/kepercayaa masyarakat yang bertentangan dengan ajaran-ajaran dan hukum Agama. Di antara ajaranajaran/perbuatan-perbuatan pada pemeluk aliran-aliran tersebut sudah banyak yang telah menimbulkan hal-hal yang melanggar hukum, memecah persatuan Nasional dan menodai Agama. Dari kenyataan teranglah, bahwa aliran-aliran atau organisasi-organisasi kebatinan/kepercayaan masyarakat yang menyalahgunakan dan/atau mempergunakan agama sebagai pokok, pada akhir-akhir ini bertambah banyak dan telah berkembang ke arah yang sangat membahayakan agama-agama yang ada."

Namun demikian, Putusan Mahkamah Konstitusi nomor 97/PUU-XIV/2016 menunjukkan cara pandang yang berbeda terhadap penghayat Kepercayaan. Cara pandang yang berbeda tersebut dapat kita lihat dalam pertimbangan hakim Mahkamah Konstitusi. Terdapat pergeseran jika dibandingkan dengan cara pandang negara saat membentuk Undang Undang PNPS Tahun 1965. Dimana dalam Undang-Undang ini negara membedakan pemeluk agama dan kepercayaan, serta pengakuan terhadap agama mayoritas, sedangkan dalam putusan Mahkamah Konstitusi justru sebaliknya, pemeluk kepercayaan dianggap sebagai warga negara dengan kedudukan yang setara. Dalam putusan ini, majelis hakim 
mengakui adanya diskriminasi/pembedaan negara melalui Undang-Undang Administrasi Kependudukan yang tidak didasarkan pada alasan yang konstitusional: "demikian juga apabila dikaitkan dengan jaminan yang sama di hadapan hukum dan pemerintahan, sejak awal penganut kepercayaan sudah dibedakan dengan penganut agama yang diakui sesuai dengan peraturan perundang-undangan dimana pembedaan demikian, sebagaimana pertimbangan di atas, tidak didasarkan pada alasan yang konstitusional. Sementara kewajiban untuk menjunjung tinggi hukum dan pemerintahan tetap melekat pada mereka sebagai warga negara Indonesia..." (Mahkamah Konstitusi, 2016).

Putusan Mahkamah Konstitusi ini sesungguhnya memberikan jawaban atas perjuangan kelompok penghayat yang selama ini dibedakan dari agama yang diakui negara. Dikotomi (pembedaan) agama yang diakui (agama resmi) dan tidak diakui secara tegas dinyatakan sebagai diskriminasi oleh majelis hakim. Dalam pertimbangannya, hakim juga berpendapat bahwa tanggung jawab negara untuk menjamin dan melindungi hak atau kemerdekaan untuk menganut agama yang hanya terbatas pada hak bagi pemeluk agama yang diakui sesuai dengan peraturan perundang-undangan tidak sejalan dengan jiwa UUD 1945. Artinya, hak untuk menganut agama tidak hanya terbatas bagi pemeluk agama yang diakui oleh peraturan perundang-undangan, tetapi juga untuk agama lain serta penghayat kepercayaan. Oleh karenanya, Pasal 61 ayat 2 UU Administrasi Kependudukan (yang menyebutkan pembedaan penghayat kepercayaan dengan agama yang diakui berdasarkan peraturan perundang-udangan) dinyatakan bertentangan dengan UUD 1945. Putusan ini bersifat erga omnes, mengikat sejak dibacakan sebagai Undang-Undang. Telah ada beberapa kajian yang membahas akibat hukum putusan ini, khususnya terkait pemenuhan hak atas administrasi kependudukan dan hak dasar lainnya seperti pendidikan, perkawinan dan kesehatan, namun belum ada yang mencoba melihat akibat hukum putusan ini dan kaitannya dengan hak beragama dan berkepercayaan bagi penghayat kepercayaan (meliputi hak memeluk dan menjalankan ibadah bagi penghayat kepercayaan).

Berdasarkan pada beberapa hal di atas, tulisan ini membahas; pertama, sejarah diskriminasi hingga pengakuan terhadap penghayat kepercayaan di Indonesia. Kedua, bentuk pengakuan Negara setelah putusan MK Nomor 97/PUU-XIV/2016 terhadap penghayat kepercayaandi Indonesia. Ketiga, dampak hukum putusan MK Nomor 97/PUUXIV/2016 terhadap hak untuk memeluk dan menjalankan ibadah bagi penghayat kepercayaan di Indonesia.

\section{Kerangka Teori}

Tulisan ini akan menggunakan tiga kerangka teori/pendekatan: pertama, kerangka teori negara hukum; kedua, Hak Asasi Manusia; ketiga, teori politik agama. Terkait teori negara hukum, Pasal 1 ayat (3) UUD Tahun 1945, menyatakan bahwa, "Indonesia adalah Negara hukum". Menurut A.V. Dicey, terdapat 3 (tiga) unsur utama, yaitu supremasi aturan-aturan hukum, persamaan di hadapan hukum dan terjaminnya hak asasi manusia dalam konstitusi serta oleh lembaga peradilan (Siallagan, 2016). Dalam konteks Negara hukum, diharuskan terjaminnya Hak Asasi Manusia (HAM). Indonesia dalam UUD NRI Tahun 1945 telah tercantum HAM, yakni dalam Bab XA Pasal 28A sampai dengan 28J.

Brian Tamanaha, membedakan tentang negara hukum ke dalam 2 (dua) kelompok yakni negara hukum formal (thin/tipis) dan negara hukum substantif (thick/tebal). Untuk menjadi negara hukum yang subtantif ada beberapa persyaratan yang harus dipenuhi yaitu adanya pengakuan hak fundamental/hak dasar, demokrasi dan menjunjung tinggi keadilan (Tamanaha, 2007). Maksudnya bahwa negara tidak hanya menjadi "penjaga malam", namun negara harus lebih aktif memberikan keadilan bagi masyarakatnya dengan pemenuhan dan perlindungan terhadap hak-hak dasar dalam negara yang demokratis.

Pendekatan Kedua adalah Hak Asasi Manusia (HAM). HAM yang menjadi rujukan adalah hak untuk memeluk agama dan kepercayaan. Dalam Undang Undang Dasar Negara Republik Indonesia tahun 1945 hak ini dijamin dalam Pasal 29 dan Pasal 28 E (UUD RI Tahun 1945). Selajutnya, Pasal 18 ayat 1 Undang-Undang Nomor 12 Tahun 2005 Tentang Pengesahan Kovenan Internasioal Hak Sipil dan Politik menterjemahkan Hak Kebebasan Beragama dan Berkeyakinan dalam 8 (delapan) elemen (Margiyono et al., 2010).

1. Kebebasan internal (forum internum): Hak setiap orang untuk berfikir, berkeyakinan dan beragama. Hak ini juga termasuk hak setiap orang untuk berpindah agama.

2. Kebebasan eksternal (forum externum): Setiap orang baik sendiri-sendiri maupun bersama-sama, di ruang publik atau privat berhak memanifestasikan agama dan kepercayaan dalam pengajaran, penataan, ibadah, dan pengalaman. 
3. Tidak ada paksaan: Tidak seorang pun dapat dipaksa sehingga terganggu kebebasannya untuk menganut atau menetapkan agama atau sesuai keyakinan dan pilihannya.

4. Tidak diskriminatif: Negara menjamin kebebasan beragama untuk semua orang tanpa terkecuali.

5. Hak Orang Tua dan Wali: Negara menjamin hak setiap orang tua untuk memberi pendidikan agama dan moral bagi anak-anak mereka sesuai keyakinan mereka sendiri.

6. Kebebasan lembaga dan status legal: Pemeluk agama atau kepercayaan bebas mendirikan organisasi termasuk kemandirian dalam pengaturan organisasinya.

7. Pembatasan yang diizinkan: Hak ini bisa dibatasi oleh Undang-Undang hanya dalam keadaan tertentu, yaitu keselamatan dan ketertiban publik, kesehatan dan kesusilaan umum, serta hak-hak dasar orang lain.

8. Tidak dapat dikurangi: Negara tidak dapat megurangi hak atas kebebasan beragama dalam keadaan apapun.

Menurut komentar umum Komite Hak Asasi Manusia Perserikatan Bangsa Bangsa (Komite HAM PBB) pasal 18 mengandung dua aspek, yaitu kebebasan beragama dan berkepercayaan serta kebebasan menjalankan agama dan kepercayaan. Bentuk intervensi negara dalam hak kebebasan beragama dan berkepercayaan hanya bisa pada ranah forum externum. Intervensi ini harus didasarkan pada Undang-Undang dan dengan alasan bahwa ajaran membahayakan hak-hak asasi yang mendasar, misalnya hak untuk hidup para pengikut agama tersebut dan masyarakat sekitar. Salah satu contoh pelarangan negara terhadap suatu sekte terjadi di Mexico, yaitu pelarangan terhadap "Sekte Hari KiamatDavid Coresh" karena dianggap membahayakan nyawa pengikutnya (Sumbulah, 2014).

Selain hal tersebut, tidak boleh ada pembatasan apapun terhadap hak ini. Hak ini dilindungi tanpa pengecualian. Norma-norma ini jelas memberikan kewajiban kepada negara untuk memberikan perlindungan dan penghormatan terhadap hak kebebasan beragama tersebut. Dengan demikian, negara tidak memiliki hak untuk menyatakan apakah suatu agama atau kelompok kepercayaan sesat atau tidak (Sumbulah, 2014).

Dalam mendiskusikan hak-hak bagi penghayat kepercayaan, penulis juga merujuk ketentuan Pasal 27 Kovenan Hak Sipil dan Politik sebagaimana telah disahkan dalam Undang-Undang Nomor 12 Tahun 2005 Tentang Pengesahan Kovenan Internasioal Hak Sipil dan Politik: "Di negara-negara dimana terdapat golongan minoritas berdasarkan etnis, agama atau bahasa, orang-orang yang tergabung dalam kelompok minoritas tersebut tidak dapat diingkari haknya, dalam komunitas bersama aggota lain dari kelompok mereka, untuk menikmati budaya mereka sendiri, untuk menjalankan dan mengamalkan agama mereka sendiri, atau untuk menggunakan bahasa mereka sendiri" (UU Nomor 12 Tahun 2005).

Siapakah kelompok minoritas tersebut? Pelapor khusus PBB untuk Perlindungan hak minoritas Francesco Capotorti mendefinisikannya dan mengategorikannya dalam 4 (empat) hal: Pertama, jika jumlah kelompok tersebut lebih kecil dibandingkan sisa populasi lainnya dalam sebuah negara; Kedua, posisinya tidak dominan dalam konteks negara; Ketiga, terdapat tiga perbedaan utama terkait etnik, agama dan bahasa dari sisa populasi lainnya; Keempat, memiliki solidaritas antar sesamanya, membagi bersama keinginan untuk melestarikan agama, bahasa, tradisi, budaya dan kepentingan untuk meraih persamaan di hadapan hukum (Margiyono et al., 2010).

Pendekatan ketiga adalah teori politik agama. Teori ini menunjukan bahwa agama, kepercayaan, adat, budaya dan seterusnya adalah konstruksi politik dengan tujuan untuk melegitimasi kuasa dan kontrol oleh kelompok (agama) tertentu atas yang lain (kepercayaan, adat dan budaya) (Maarif, 2018). Politik agama tersebut dilakukan melalui mobilisasi dan tekanan publik atas nama identitas (agama) mayoritas dan infiltrasi terhadap negara. Negara yang diinfiltrasi cenderung mengeluarkan kebijakan dan peraturan perundang-undangan atas nama politik agama yang mengklasifikasikan warga negara menjadi 2 (dua), yaitu kleompok yang layak dilayani (penganut agama resmi) dan kelompok yang tidak dapat dilayani (kelompok penganut agama lokal/kepercayaan) (Maarif, 2019).

\section{Metode Penelitian}

Jenis penelitian yang digunakan dalam studi ini adalah penelitian hukum normatif (normative law research), menggunakan bahan hukum yang berasal dari bahan hukum primer, sekunder dan lainnya. Bahan hukum primer adalah UUD NRI 1945, dan peraturan lainnya. Bahan hukum sekunder adalah bahan hukum yang berupa buku-buku hukum 
yang berisi ajaran dan doktrin, terbitan berkala berupa artikel-artikel tentang ulasan hukum yang berkaitan dengan Penghayat Kepercayaan salah satunya adalah hasil The First International Conference on Indigenous Religion, yang diselelnggarakan oleh Center for Religious dan Cross-cultural Studies (CRCS), Universitas Gadjah Mada pada tanggal 1-3 Juli 2019. Bahan hukum lainnya adalah bahan penunjang tambahan bahan hukum primer dan sekunder, meliputi jurnal hukum dan ulasan hukum yang diterbitan oleh perguruan tinggi dan kasus-kasus yang berkaitan dengan Penghayat Kepercayaan. Bahan hukum tersebut dianalisa secara yuridis normatif atau analisis kualitatif atau studi dokumen dengan menggunakan literatur yang berhubungan dengan kesetaraan Penghayat Kepercayaan, serta menggunakan pendekatan Peraturan Perundang-Undangan, sejarah hukum serta studi kasus.

\section{Dinamika Menuju Pengakuan Penghayat Kepercayaan di Indonesia 4.1. Sejarah Diskriminasi Sampai Dengan Pengakuan Penghayat Kepercayaan di Indonesia}

Pada bagian ini penulis akan sedikit melihat baik diskriminasi maupun pengakuan negara terhadap penghayat kepercayaan. Penulisan didasarkan pada terbitnya berbagai peraturan serta peristiwa penting terkait Penghayat Kepercayaan. Penulisan ini dimulai sejak pembahasan UUD 1945, sampai dengan dikabulkannya uji materi Undang-Undang Tentang Administrasi Kependudukan.

\subsubsection{Diakuinya Hak Beragama dan Beribadah Dalam Penyusunan UUD 1945}

Dalam penyusunan UUD 1945 oleh Badan Penyelidik Upaya Persiapan Kemerdekaan Indonesia (BPUPKI), terdapat debat yang panjang perihal negara dan agama. Diskusi ini terjadi baik saat pembahasan dasar negara pada tanggal 30 Mei sampai dengan 1 Juni 1945 dan diulang lagi pada saat pembahasan Batang Tubuh, yaitu pada tanggal 15-16 Juli 1945. Pada tanggal 31 Mei 1945, Soepomo berpidato dan memberitahukan tentang rencana pendirian Negara Islam. Menurutnya, Negara Islam tidak sesuai dengan Indonesia jika akan mendirikan negara persatuan. Dengan mendirikan Negara Islam akan timbul soal-soal minderheden (keterpinggiran) untuk agama yang lain. Meskipun Negara Islam akan menjamin sebaik-baiknya golongan agama yang lain. Namun golongan itu tidak dapat mempersatukan dirinya dengan Negara (Bahar et al., 1995).

Selanjutnya pada 1 Juni 1945, dalam pidatonya Ir. Soekarno kembali menegaskan bahwa kita sedang mendirikan 1 (satu) Negara Kebangsaan. Dasar kebangsaan artinya bukan kebangsaan dalam arti sempit, melainkan sebuah nationale staat yang berdiri dari ujung Sumatera sampai Irian. Selanjutnya Ir. Soekarno menambahkan bahwa Indonesia adalah Negara yang Berketuhanan: "Hendaknya negara Indonesia ialah negara yang tiaptiap orangnya dapat menyembah Tuhannya dengan cara yang leluasa. Segenap rakyat hendaknya bertuhan secara "kebudayaan", yakni tiada egoism agama" (Bahar et al., 1995).

Pendiskusian mengenai negara dan agama kembali muncul ketika salah satu anggota BPUPKI bertanya terkait Pasal 28 UUD 1945, yaitu hak untuk beragama dan beribadah, serta pasal tentang syarat menjadi Presiden Indonesia adalah orang yang beragama islam. Tarik menarik antara kelompok Nasionalis dan Islam terjadi. Kelompok Nasionalis berjuang agar negara Indonesia adalah negara yang bersatu, tidak hanya berdasarkan 1 (satu) agama. Selain itu, Wongsonegoro mengusulkan kemerdekaan untuk beribadah juga ditujukan kepada aliran kebatinan (Abidin et al., 2019). Akhirnya disepakati Pasal 28 (yang kemudian menjadi pasal 29, karena disisipkan pasal tentang hak berserikat dan berkumpul pada pasal 28) dengan isi: 1) Negara berdasarkan atas Ketuhanan Yang Maha Esa. 2) Negara menjamin kemerdekaan tiap-tiap penduduk untuk memeluk agamanya masing-masing dan untuk beribadat menurut agamanya dan kepercayaannya itu. Ada 2 (dua) tafsir terhadap kata "kepercayaan" dalam ayat 2, tafsir pertama adalah kepercayaan terhadap agamanya, tafsir kedua adalah aliran kepercayaan. Terlepas dari 2 (dua) tafsir itu, setidaknya jaminan dalam Pasal 29 juga berlaku bagi seluruh agama termasuk agama lokal atau aliran kebatinan yang saat ini dikenal sebagai kepercayaan.

\subsubsection{Pendirian Departemen Agama}

Pada 3 Januari 1946 Departemen Agama didirikan. Departemen ini diusulkan pada saat sidang Komite Nasional Indonesia Pusat (KNIP), pada kabinet Sjahrir. Keberadaan departemen ini salah satunya agar hal-hal yang berkaitan dengan keagamaan dapat terlayani, karena pada masa Hindia Belanda urusan ini tidak terlayani dengan baik. 
Menurut Peraturan Pemerintah Nomor 33 Tahun 1949 dan Peraturan Pemerintah Nomor 8 Tahun 1950 serta Peraturan Menteri Agama Nomor 5 Tahun 1951, antara lain menetapkan kewajiban dan lapangan tugas Kementerian Agama yaitu:

1. Melaksanakan asas Ketuhanan Yang Maha Esa dengan sebaik-baiknya;

2. Menjaga bahwa tiap-tiap penduduk mempunyai kemerdekaan untuk memeluk agamanya masing-masing dan untuk beribadat menurut agamanya dan kepercayaannya;

3. Membimbing, menyokong, memelihara dan mengembangkan aliran-aliran agama yang sehat;

4. Menyelenggarakan, memimpin dan mengawasi pendidikan agama di sekolah-sekolah negeri;

5. Memimpin, menyokong serta mengamat-amati pendidikan dan pengajaran di madrasah-madrasah dan perguruan-perguruan agama lain-lain;

6. Mengadakan pendidikan guru-guru dan hakim agama;

7. Menyelenggarakan segala sesuatu yang bersangkut paut dengan pengajaran rohani kepada anggota-anggota tentara, asrama-asrama, rumah-rumah penjara dan tempat-tempat lain yang dipandang perlu;

8. Mengatur, mengerjakan dan mengamat-amati segala hal yang bersangkutan dengan pencatatan pernikahan, rujuk dan talak orang Islam;

9. Memberikan bantuan materiil untuk perbaikan dan pemeliharaan tempat-tempat beribadat (masjid-masjid, gereja-gereja dll);

10. Menyelenggarakan, mengurus dan mengawasi segala sesuatu yang bersangkut paut dengan Pengadilan Agama dan Mahkamah Islam Tinggi;

11. Menyelidiki, menentukan, mendaftarkan dan mengawasi pemeliharaan wakaf-wakaf;

12. Mempertinggi kecerdasan umum dalam hidup bermasyarakat dan hidup beragama.

Keberadaan Departemen Agama menjadi cerita tersendiri bagi penghayat kepercayaan. Departemen ini selain memiliki wewenang mengatur agama-agama besar seperti Islam, Kristen, Katolik, Hindu, Budha, awalnya juga mengurus aliran kebatinan atau aliran kepercayaan. Walaupun pada perkembangan selanjutnya akan dipisahkan, karena kebatinan atau kepercayaan bukanlah agama. Hal ini karena kepercayaan tidak masuk dalam definisi agama yang ditetapkan oleh Departemen Agama.

\subsubsection{Lahirnya Pengawas Aliran Kepercayaan Masyarakat (PAKEM)}

Tahun 1952 Departemen Agama membuat definisi tentang Agama, yaitu: 1. Memiliki Kitab Suci; 2. Memiliki Nabi; 3. Adanya pengakuan internasional (Rumadi et al., 2008). Keberadaan definisi ini membuat aliran kebatinan atau penghayat kepercayaan tidak masuk dalam definisi agama. Selanjutnya, Departemen Agama melaporkan bahwa pada tahun ini terdapat 360 agama baru dan kebatinan. Berdasarkan laporan tersebut, dibentuklah Pengawas Aliran Kepercayaan Masyarakat (PAKEM) pada tahun 1953 (Rumadi et al., 2008). Keberadaan PAKEM membawa dampak yang cukup besar bagi penghayat kepercayaan. PAKEM pada praktiknya akan memaksa pemeluk kepercayaan untuk memilih salah satu dari 5 (lima) agama resmi. PAKEM selain mengawasi, juga berwenang melakukan pemeriksaan, bahkan membubarkan organisasi atau kelompok kepercayaan. Badan ini berada di bawah koordinasi Kejaksaan Agung yang anggotanya adalah kepolisian, TNI, Pemerintah Daerah dan Kejaksaan (Abidin et al., 2019).

\subsubsection{G30 S PKI dan UU No. 1 PNPS Tahun 1965}

Peristiwa yang biasa dikenal dengan G30 SPKI memberi dampak tersendiri bagi penghayat kepercayaan. Pada masa ini terjadi perpindahan besar-besaran dari penghayat kepercayaan untuk memilih salah satu agama yang dianggap sebagai agama yang diakui karena dipaksa (Rumadi et al., 2008). Jika tidak memilih agama, mereka bisa saja disebut sebagai komunis. Organisasi bisa dibubarkan dan anggota maupun pemimpin bisa saja ditangkap dan dibuang. Di Banyumas, pemeluk Kawruh naluri (KWN) dipaksa memilih salah satu dari 5 (lima) agama, sebagian diantara mereka memilih beragama Budha, dan sebagian lain memilih beragama Kristen (Abidin et al., 2019). Hal yang sama juga terjadi pada kelompok yang mengikuti Eyang Bonokeling di Banyumas. Kelompok ini dicap sebagai pengikut PKI dan dikejar-kejar oleh masyarakat (Nawawi et al., 2016). Peristiwa ini membawa trauma yang luar biasa bagi penganut kepercayaan, seperti yang diakui oleh Dewi Kanti, pemeluk 
Sunda Wiwitan yang menyatakan bahwa yang terjadi selama ini terhadap penghayat adalah kekerasan yang terstruktur (Lestari, 2016).

Diskriminasi semakin jelas ketika pemerintah menerbitkan Undang-Undang Nomor 1 PNPS Tahun 1965 Tentang pencegahan penyalahgunaan dan/atau penodaan agama. Keberadaan Undang-Undang ini menjadi dasar adanya agama "resmi" atau "diakui" dan agama "tidak resmi" atau "tidak diakui". Penghayat kepercayaan tentu masuk kategori lainnya, karena dianggap bukan agama. Keberadaan Undang-Undang ini juga menjadi dasar pengawasan aliran kepercayaan, dimana pemeluk kepercayaan dianggap sebagai ancaman. Keberadaan Undang-Undang ini menjadi dasar hukum bagi Badan Koordinasi Pengawas Aliran Kepercayaan Masyarakat (BAKOR PAKEM) untuk megawasi, melarang bahkan membubarkan organisasi penghayat.

Penerbitan Undang Undang ini terjadi dalam konteks keberadaan kelompok santri yang telah menjadi bagian dari negara melalui Departemen Agama yang menekan kelompok "abangan", dimana penghayat kepercayaan masuk di dalamnya (Maarif, 2019). Penyempitan definisi agama adalah dengan tujuan mempersempit peluang kelompok abangan untuk mendirikan agama baru. Menurut Syamsul Maarif dalam bukunya "Pasang Surut Rekognisi Agama Leluhur" perkembangan kelompok penghayat merupakan ancaman bagi kelompok santri, karena berpotensi mendirikan agama baru. Oleh karenanya dibentuklah Pengawas Aliran Kepercayaan/PAKEM atau dikenal juga dengan sebutan BAKOR PAKEM agar perkembangan kelompok penghayat kepercayaan dapat diawasi (Maarif, 2019).

Pada periode 1971 s/d 1983 tercatat Kejagung telah melakukan pelarangan terhadap 6 (enam) aliran kepercayaan/kebatinan dan juga sekte di dalam agama-agama resmi, yaitu: a. Aliran Darul Hadist, Islam Jemaah, JPID Jappenas DII organisasi yang bersifat/berjaran serupa; b. Aliran Kepercayaan Manunggal; c. Agama Budha Jawi Wisnu; d. Ajaran Agama Jawa Sanyoto; e. Saksi Yehova; f. Ajaran yang dikembangkan oleh Abdul Rahman dan pengikutnya (Aliran Inkarsunnah) dan larangan beredarnya buku tulisan tangan karangan Moch. Icham Sutarto (Rumadi et al., 2008). Selain beberapa aliran ini, kelompok yang lain juga mendapatkan peringatan untuk mengganti nama organisasi, masuk atau memilih agama yang diakui seperti yang terjadi pada kelompok Kawruh Naluri di Banyumas dan Gombong, Jawa Tengah (Abidin et al., 2019).

Sesungguhnya pada tahun 2009, Undang-Undang Nomor 1/PNPS tahun 1965 pernah diajukan uji materi ke Mahkamah Konstitusi. Uji materi ini didasarkan pada banyaknya kasus-kasus penodaan agama yang diadukan ke LBH Jakarta (Hidayat, 2011). Pada uji materi ini beberapa kelompok penghayat menjadi pihak terkait, juga saksi. Salah satu penghayat dalam kesaksiannya menyebutkan bahwa ia tidak bisa mejadi ABRI karena ia Penghayat. Ia sempat ditertawakan dalam sidang karena meminta kepada Majelis Hakim untuk disumpah dengan sumpah Pancasila. Uji materi berlangsung tegang karena setiap sidang dihadiri oleh ribuan masa dari berbagai organisasi Islam. Uji materi ini dinyatakan ditolak oleh Mahkamah Konstitusi (Margiyono et al., 2010).

\subsubsection{Musyawarah Nasional Penghayat I}

Pada tahun 1970 diselenggarakan Musyawarah Nasional (Munas) Kepercayaan (Kebatinan, Kejiwaan, Kerohanian) yang diketuai oleh Mr. K.R.M.T Wongsonegoro. Seperti yang kita tahu, Mr. K.R.M.T Wongsonegoro adalah perumus naskah UUD 1945. Pada musyawarah ini dikenal istilah kepercayaan yang sebelumnya dikenal dengan aliran kebatinan. Munas ini membentuk Sekretariat Kerja Sama Kepercayaan (kebatinan, kejiwaan, dan kerohanian) [SKK]. SKK merupakan wadah pengganti Badan Kongres Kebatinan Indonesia (BKKI) (Abidin et al., 2019).

Selanjutnya, pada Munas III tanggal 18 November 1979 di Tawangmangu, SKK diubah menjadi Himpunan Penghayat Kepercayaan terhadap Tuhan Yang Maha Esa (TYME) yang disingkat dengan HPK dari tingkat pusat, Daerah Tingkat (DATI) I (tingkat provinsi), DATI II (tingkat kabupaten/kota), dan kecamatan secara Nasional. HPK bertujuan (1) terlaksananya pedoman penghayatan dan pengamalan Pancasila (P4), (2) terpeliharanya budaya bangsa dan kepribadian Nasional terutama yang berhubungan langsung dengan perikehidupan kepercayaan terhadap TYME dalam usaha membangun manusia Indonesia seutuhnya, (3) tertampungnya segala aspek perikehidupan kepercayaan terhadap TYME dalam perlindungan hukum negara RI, (4) menjadi wadah tunggal bagi masyarakat Penghayat Kepercayaan terhadap TYME, (5) Memayu hayuning bawana (Abidin et al., 2019). 
Dalam perkembangannya, HPK bubar dan berubah menjadi Badan Koordinasi Organisasi Kepercayaan (BKOK). Namun saat ini, BKOK juga telah berubah menjadi Majelis Luhur Kepercayaan Terhadap Tuhan Yang Maha Esa (MLKI). MLKI berdiri pada tahun 2014. Tujuan MLKI adalah: 1. Membina kerjasama antar anggotanya agar mampu menjalin komunikasi dan beradaptasi dengan lingkungan masyarakat di luar organisasi-organisasi kepercayaan. 2. Melestarikan nilai-nilai luhur spiritual bangsa 3. Ikut serta membentuk dan membangun karakter manusia Indonesia seutuhnya di bidang mental-spiritual yang berjiwa Pancasila (Banu, 2018).

\subsubsection{Pengesahan Undang-Undang Perkawinan}

Keberadaan Undang-Undang Nomor 1 tahun 1974 Tentang Perkawinan membawa akibat yang sangat besar bagi penganut aliran kepercayaan. Keberadaan undang-undang ini belum cukup kuat meningkatkan posisi tawar penganut aliran kepercayaan di hadapan Pegawai Pencatat Perkawinan dalam hal mencatatkan perkawinannya. Dapat dicatatkannya perkawinan dengan cara sesuai dengan adat atau sesuai kepercayaan yang dianut tergantung pada Kantor Pencatatan Sipil. Jika kita melihat definisi perkawinan yang sah menurut Pasal 2 ayat (1) Undang-Undang ini adalah: Perkawinan adalah sah, apabila dilakukan menurut hukum masing-masing agamanya dan kepercayaannya itu. Walaupun frasa 'kepercayaan' tertulis dalam pasal tersebut, dalam praktiknya Penghayat Kepercayaan masih sulit mencatatkan perkawinan berdasarkan Undang-Undang ini (Viri, 2008).

Dalam perkembangannya pencatatan perkawinan penghayat diatur dalam UndangUndang Tentang Administrasi Kependudukan. Dalam Undang-Undang ini, penghayat bisa mencatatkan perkawinannya di hadapan pemuka penghayat yang telah didaftar di Direktorat Kepercayaan, Kementerian Pendidikan dan Kebudayaan. Walaupun demikian, tidak semua penghayat mau mengorganisir diri dalam organisasi dan mendaftarkan pemukanya. Hal ini erat kaitannya dengan sejarah kelam pembubaran organisasi, sehingga banyak penghayat yang tidak mau berorganisasi. Akibatnya jika tidak berorganisasi maka perkawinan tidak bisa dicatatkan. Atau jika mau, penghayat harus masuk ke salah satu organisasi agar bisa dicatatkan perkawinannya.

\subsubsection{TAP MPR Tentang Garis Garis Besar Haluan Negara-Kepercayaan Bukan Agama}

Dalam GBHN Tahun 1978, disebutkan bahwa "Kepercayaan Terhadap Tuhan Yang Maha Esa bukan agama. Pembinaan terhadap Kepercayaan dilakukan: 1. Agar tidak mengarah pada pembentukan agama baru; 2. Untuk mengefektifkan pengambilan langkah yang perlu agar pelaksanaan kepercayaan terhadap Tuhan Yang Maha Esa menurut dasar kemanusiaan yang adil dan beradab". Akibat hukum dari adanya ketentuan ini adalah dikeluarkannya pengurusan kepercayaan dari Departemen Agama dan dimasukan dalam Departemen Pendidikan dan Kebudayaan. Ketentuan dalam GBHN ini kemudian melanggengkan dikotomi/pembedaan antara pemeluk agama dan kepercayaan.

\subsubsection{Pengesahan pasal $28 \mathrm{E}$ ayat (2) dalam Amandemen UUD 1945}

Keberadaan Pasal 28E ayat (2) UUD 1945 menjadi jaminan konstitusional bagi Penghayat Kepercayaan. Pasal ini berisi: "Setiap orang berhak untuk kebebasan meyakini kepercayaan, menyatakan pikiran dan sikap, sesuai dengan hati nuraninya". Jika dibandingkan dengan Pasal 29, pasal ini lebih jelas menggambarkan pengakuan negara terhadap pemeluk kepercayaan. Keberadaan Pasal 28E ayat 2 menguatkan jaminan yang ada pada pasal 29 UUD 1945.

\subsubsection{Pengesahan Undang-Undang Admnistrasi Kependudukan}

Undang-Undang Nomor 23 Tahun 2006 Tentang Administrasi Kependudukan merupakan peraturan yang menjadi payung hukum dalam memberikan perlindungan, pengakuan, penentuan status pribadi dan status hukum setiap Peristiwa Kependudukan dan Peristiwa Penting yang dialami oleh Penduduk Indonesia dan Warga Negara Indonesia (WNI) yang berada di luar wilayah Negara Kesatuan Republik Indonesia (NKRI). Peristiwa Kependudukan adalah kejadian yang dialami penduduk yang harus dilaporkan karena membawa akibat terhadap penerbitan atau perubahan Kartu Keluarga (KK), Kartu Tanda Penduduk (KTP) dan/atau surat keterangan kependudukan lainnya meliputi pindah datang, perubahan alamat, serta status tinggal terbatas menjadi tinggal tetap. Sedangkan peristiwa penting adalah kejadian yang dialami oleh seseorang meliputi kelahiran, 
kematian, lahir, mati, perkawinan, perceraian, pengakuan anak, pengesahan anak, pengangkatan anak, perubahan nama dan perubahan status kewarganegaraan.

Ada beberapa permasalahan yang ada dalam Undang-Undang Administrasi Kependudukan yang masih mendiskriminasikan penghayat kepercayaan. Beberapa masalah tersebut antara lain: Bagi Penghayat Kepercayaan, bisa mendapakan KTP hanya saja dalam kolom agama bertuliskan (-). Dalam Undang-Undang ini misalnya pada pasal 8 ayat (4) terdapat frasa "...bagi Penduduk yang agamanya belum diakui sebagai agama menurut peraturan perundang-undangan atau bagi penghayat kepercayaan berpedoman pada peraturan perundang-undangan." Frasa ini menguatkan dikotomi atau pembedaan antara agama yang diakui dan tidak diakui sebagaimana disebutkan dalam UndangUndang Nomor 1/PNPS Tahun 1965 (UU Nomor 1 Tahun 1965).

Namun, seiring perkembangan zaman terjadi perubahan Undang-Undang No. 23 Tahun 2006 (UU Nomor 23 Tahun 2006) menjadi Undang-Undang Nomor 24 Tahun 2013 Tentang Administrasi Kependudukan yang telah disahkan oleh DPR RI pada tanggal 26 November 2013 (UU Nomor 24 Tahun 2013). Perubahan yang mendasar di bidang administrasi kependudukan. Tujuan utama dari perubahan Undang-Undang tersebut untuk meningkatkan efektivitas pelayanan administrasi kependudukan kepada masyarakat, menjamin akurasi data kependudukan dan ketunggalan Nomor Induk Kependudukan (NIK) serta ketunggalan dokumen kependudukan. Salah satu perubahannya yaitu masa pemberlakuan KTP elektonik yang diatur dalam Pasal 64 ayat (4) berlaku 5 (lima) tahun menjadi seumur hidup, sepanjang tidak ada perubahan atas elemen data penduduk dan berubahnya domisili penduduk.

\subsubsection{Peraturan Menteri Pendidikan dan Kebudayaan tentang Pendidikan Penghayat}

Pada tahun 2016, Menteri Pendidikan dan Kebudayaan menerbitkan Peraturan Menteri Pendidikan Nomor 27 Tahun 2016 Tentang Layanan Pendidikan Kepercayaan Terhadap Tuhan Yang Maha Esa pada Satuan Pendidikan (Peraturan Kemendikbud Nomor 27 Tahun 2016). Dengan adanya Permendikbud ini siswa-siswi penghayat bisa memiliki kurikulum dan mengikuti pendidikan penghayat untuk mata pelajaran agama. Jika sebelumnya siswasiswi Penghayat diminta memilih salah satu dari 6 (enam) agama, saat ini mereka bisa belajar dengan kurikulum penghayat khusus untuk mata pelajaran pendidikan agama/kepercayaan. Keberadaan peraturan ini juga menunjukkan pengakuan dan pemenuhan negara atas hak siswa-siswi untuk belajar sesuai dengan apa yang diyakininya.

\subsubsection{Dikabulkannya Permohonan Uji Materi di Mahkamah Konstitusi}

Permohonan judicial review diajukan oleh Nggay Mehang Tana, Pagar Damanra Sirait, Arnol Purba dan Carlim sebagai pemohon dengan nomor perkara 97/PUU-XIV/2016. Pemohon mengajukan permohonan bertanggal 28 September 2016. Pemohon I adalah penganut kepercayaan dari Komunitas Marapu di Sumba Timur, Pulau Sumba. Terdapat 21.000 orang penganut kepercayaan Komunitas Marapu dan sebanyak 40 ribu orang yang terlanggar hak atas layanan kependudukannya. Identitasnya sebagai penganut kepercayaan, perkawinan antar pemeluk kepercayaan dari Komunitas Marapu yang dilakukan secara adat tidak diakui Negara. Akibatnya, anak-anak mereka sulit mendapatkan Akta Kelahiran, demikian pula dengan KTP elektronik, yang sebagian penganutnya terpaksa berbohong menuliskan agama di luar kepercayaannya agar bisa mendapatkan KTP elektronik dengan mudah. Begitupun dengan Pemohon II penganut kepercayaan Parmalim di Sumatera Utara. Penganut kepercayaan Parmalim mengalami berbagai permasalahan dan eksklusi dari aspek pemenuhan hak-hak dasar dan kebijakan publik, yakni banyaknya ketidakcocokan antara identitas agama yang dituliskan di KK dan KTP elektronik. Dan pihak yang bertugas mengurus KK dan KTP elektronik tersebut sering memaksa untuk memilih agama yang diakui agar proses pembuatannya lebih mudah. Dan terdapat kerugian konstitusional ketika disyaratkan berpindah agama terlebih dahulu apabila mau diterima pada pekerjaan yang dilamarnya.

Pemohon III penganut kepercayaan Ugamo Bangsa Batak di Medan, Sumatera Utara. Bahwa kolom agama di KK dan KTP elektonik untuk kepercayaan dikosongkan, secara tidak langsung telah mengalami diskriminasi, serta anak dari Pemohon III telah terlanggar haknya untuk bekerja yakni ditolak melamar pekerjaan meskipun nilai dan prestasinya bagus. Penolakan tersebut karena kolom agama di KTP elektoniknya bertanda strip (-). Calon pemberi kerja menganggap bahwa strip identik dengan ateis atau kafir. Sedangkan Pemohon IV penganut kepercayaan Sapto Darmo. Ketika kolom agamanya kosong, mereka 
mendapat stigma sesat dari masyarakat umum. Akibat kolom agama yang kosong pula pemakaman keluarga Pemohon IV ditolak di pemakaman umum manapun di Kabupaten Brebes. Serta anak dari Pemohon IV mengalami kesulitan untuk mengakses pendidikan dan masuk sekolah tingkat dasar, karena diketahui menganut Kepercayaan Sapto Darmo dan ketika telah sekolah anak tersebut dipaksa harus mengikuti mata pelajaran dan ajaran pendidikan Agama Islam yang mana hal tersebut bertentangan dengan keyakinan dan kepercayaannya.

Pengajuan Pemohon terhadap Pasal 61 Ayat (1) dan (2), serta Pasal 64 Ayat (1) dan (5) UU Nomor 23 Tahun 2006 Tentang Administrasi Kependudukan juncto UU Nomor 24 Tahun 2013 Tentang Administrasi Kependudukan, bertentangan dengan Prinsip Negara Hukum yang dijamin dalam Pasal 1 ayat (3) UUD 1945. Pemohon juga menilai bahwa keberadaan UU Administrasi Kependudukan secara faktual merugikan hak-hak konstitusional yang dijamin oleh UUD 1945, yakni kesulitan dan tidak dapat memperoleh KK dan KTP elektronik. Para Pemohon beserta keluarga tidak dapat dicatat oleh Negara melalui sistem pencatatan KTP elektronik dan tidak mendapat Kartu Keluarga (KK).

Mahkamah Konstitusi pada 7 November 2017 mengabulkan permohonan judicial review aturan pengosongan kolom agama bagi penganut kepercayaan pada KK dan KTP elektronik. Dalam putusannya, Majelis Hakim berpendapat bahwa kata "agama" dalam Pasal 61 ayat (1) dan Pasal 64 ayat (1) bertentangan dengan UUD 1945 dan tidak mempunyai kekuatan hukum mengikat secara bersyarat sepanjang tidak termasuk penganut aliran kepercayaan. Selain itu, Majelis Hakim juga menyatakan bahwa Pasal 61 ayat (2) dan Pasal 64 ayat (5) bertentangan dengan UUD 1945 dan tidak mempunyai kekuatan hukum mengikat. Dengan demikian, penganut kepercayaan sejak putusan dibacakan Hakim Mahkamah Konstitusi, memiliki kedudukan hukum yang sama dengan pemeluk 6 (enam) agama yang telah diakui Pemerintah dalam memperoleh hak terkait administrasi kependudukan.

\subsection{Bentuk Pengakuan Negara terhadap Penghayat Kepercayaan di Indonesia}

\subsubsection{Pengakuan Dalam Putusan Mahkamah Konstitusi Nomor 97/PUU-XIV/2016}

\section{Pengakuan Terhadap Hak atas Administrasi Kependudukan}

Pada 26 Oktober 2016 sebanyak 4 (empat) penghayat kepercayaan yang bernama Nggay Mehang Tana, Pagar Damanra Sirait, Arnol Purba dan Carlim, menilai bahwa keberadaan UU Administrasi Kependudukan secara faktual merugikan hak-hak konstitusional yang dijamin oleh UUD 1945. Penghayat kepercayaan tersebut tercatat sebagai para Pemohon perkara yang diregistrasi Kepaniteraan MK. Menurut Pemohon, implikasi berlakunya Pasal 61 ayat (1) dan (2) juncto Pasal 64 ayat (1) dan (5) UU Administrasi kependudukan adalah para pemohon kesulitan dan tidak dapat memperoleh KK dan KTP elektronik. Para Pemohon beserta keluarga tidak dapat dicatat oleh Negara melalui sistem pencatatan KTP elektronik dan tidak mendapat Kartu Keluarga (KK). Komnas Perempuan mengatakan bahwa jika Kolom KTP para penghayat kepercayaan terus dibiarkan kosong atau diisi dengan tanda strip (-), maka akan terus terjadi ketidakpastian hukum, ketidakadilan, ketidaksetaaan, terhambatnya akses pendidikan dan pekerjaan yang merugikan bukan hanya para penghayat melainkan juga merugikan Bangsa (Konstitusi, 2017, pp. 13-14).

Mahkamah Konstitusi (MK) memutuskan untuk mengabulkan permohonan para Pemohon untuk seluruhnya. Menyatakan bahwa kata 'agama' dalam Pasal 61 ayat (1) dan Pasal 64 ayat (1) UU Administrasi Kependudukan bertentangan dengan UUD 1945 dan tidak mempunyai kekuatan hukum mengikat secara bersyarat sepanjang tidak termasuk 'kepercayaan'. Putusan Nomor 97/PUU-XIV/2016 dibacakan oleh Ketua Mahkamah Konstitusi Arief Hidayat dengan didampingi Hakim konstitusi lainnya pada Selasa, 7 November 2017 lalu (Mahkamah Konstitusi, 2014). Pertimbangan Hukum yang dibacakan oleh Hakim Konstitusi Saldi Isra, bahwa Mahkamah menilai keberadaan Pasal 61 dan Pasal 64 UU Administrasi Kependudukan bertujuan untuk mewujudkan tertib administrasi kependudukan dengan terbangunnya database kependudukan secara Nasional serta keabsahan dan kebenaran atas dokumen kependudukan yang diterbitkan. Upaya melakukan tertib administrasi kependudukan sebagaimana dimaksud pada pasal a quo sama sekali tidak boleh mengurangi hak-hak warga negara dimaksud termasuk hak atas kebebasan beragama dan berkeyakinan. Saldi menambahkan adanya pernyataan dalam Pasal 61 ayat (2) dan dalam Pasal 64 
ayat (5) UU Administrasi Kependudukan yang menyatakan bahwa bagi penghayat kepercayaan kolom "agama" tidak diisi, meski tetap dilayani dan dicatat dalam database Kependudukan, bukanlah dimaksudkan untuk memberikan perlindungan dan jaminan negara bagi warga negara penganut kepercayaan. Hal tersebut semata-mata penegasan tentang kewajiban Negara untuk memberikan pelayanan kepada setiap warga Negara sesuai dengan data yang tercantum dalam database kependudukan yang memang merupakan tugas dan kewajiban Negara (Konstitusi, 2017, pp. 19-20).

Dengan dikabulkannya Putusan Mahkamah Konstitusi Nomor 97/PUU-XIV/2016, maka Mahkamah memberi pengesahan kepada para penghayat kepercayaan mendapatkan pengakuan dari Negara berupa mencantumkan kepercayaan ke dalam kolom agama di Kartu Keluaraga (KK) dan KTP elektronik. Mahkamah Konstitusi (MK) telah memberikan kedudukan, memenuhi hak dasar dan keadilan kepada para penganut aliran kepercayaan di Indonesia.

2. Pengakuan terhadap Hak Memeluk dan Beribadah Bagi Penghayat Kepercayaan

Selain beberapa hal yang disebutkan di atas, sebetulnya ada hal menarik yang dapat kita lihat dalam pertimbangan hakim Mahkamah Konstitusi dalam putusan Nomor 97/PUU-XIV/2016. Hal menarik tersebut adalah pengakuan negara terhadap jaminan hak beragama bagi pemeluk kepercayaan dan pengakuan bahwa pemenuhan hak beragama hanya kepada warga yang memiliki agama yang diakui (agama resmi) adalah bentuk diskriminasi dan tidak sejalan dengan semangat UUD 1945. Pernyataan ini jelas dan tegas menyatakan bahwa cara negara membedakan antara agama yang diakui dan agama yang tidak diakui adalah bentuk diskriminasi yang bertentangan dengan Undang Undang Dasar 1945. Beberapa hal tersebut dapat dilihat dalam pertimbangan hakim berikut ini:

- "..dengan berdasar pada ketiga asas dalam penafsiran kontekstual di atas, maka telah terbukti bahwa UU Administrasi kependudukan, in casu Pasal 61 ayat 1 dan 2 dan pasal 64 ayat 1 dan 5 berpegang pada atau menganut pendirian bahwa "agama" yang dimaksud adalah agama yang diakui sesuai peraturan perundang-undangan. Dengan kata lain hak atau kemerdekaan warga negara untuk menganut agama dibatasi pada agama yang diakui sesuai peraturan perundang-undangan. Konsekuensinya, secara a contrario tanggung jawab atau kewajiban konstitusional negara untuk menjamin dan melindngi hak atau kemerdekaan warga negara untuk menganut agama yang sesungguhnya juga termasuk kepercayaan terhadap Tuhan Yang Maha Esa, juga terbatas pada warga negara yang menganut agama yang diakui sesuai peraturan perundang-undangan. Hal inilah yang tidak sejalan dengan jiwa UUD 1945 yang secara tegas menjamin bahwa tiap-tiap warga negara merdeka untuk memeluk agama dan kepercayaan dan untuk beribadah sesuai agama dan kepercayaannya itu...” (Salinan Putusan Mahkamah Konstitusi, 2016).

- "Hal lain yang lebih fundamental adalah bahwa dengan analisis tehadap rumusan norma dalam pasal 61 ayat 1 dan ayat 2 serta pasal 64 ayat 1 dan ayat 5 UU Administrasi Kependudukan berarti bahwa Undang Undang a quo secara implisit mengkostruksikan hak atau kebebasan menganut agama, yang sesungguhnya juga termasuk kepercayaan terhadap Tuhan Yang Maha Esa, sebagai pemberian negara. Padahal sebaliknya hak atau kemerdekaan menganut agama (termasuk menganut Kepercayaan Terhadap Tuhan Yang Maha Esa) adalah hak yang melekat pada setiap orang sebab hak itu diturunkan dari kelompok hak-hak alamiah (natural right) bukan pemberian negara. Oleh karena hak beragama dan menganut kepercayaan merupakan salah satu hak asasi manusia, maka sebagai negara hukum yang mempersyaratkan salah satunya adanya perlindungan terhadap hak-hak asasi manusia, sehingga membawa konsekwensi adanya tanggung jawab negara untuk menjamin bahwa hak asasi warganya benar-benar ternikmati dalam praktik atau kenyataan sehari-hari. Apalagi tatkala hak asasi tersebut tegas dicantumkan dalam konstitusi sehingga menjadi bagian dari hak konstitusional maka tanggung jawab negara untuk menjamin penikmatan hak itu jadi makin kuat karena telah menjadi kewajiban konstitusional negara untuk memenuhinya sebagai konsekwensi dari pengakuan kedudukan konstitusi (in casu UUD 1945) sebagai hukum tertinggi (supreme law)..." (Salinan Putusan Mahkamah Konstitusi, 2016).

Berdasarkan beberapa pertimbangan yang telah disebutkan di atas, Majelis Hakim dalam amar putusannya menyatakan bahwa pasal 61 ayat 2 bertentangan dengan 
Undang Undang Dasar 1945. Isi Pasal 61 ayat 2 UU Administrasi Kependudukan adalah: "Keterangan mengenai kolom agama sebagaimana dimaksud pada ayat (1) bagi Penduduk yang agamanya belum diakui sebagai agama sesuai dengan ketentuan Peraturan Perundang-undangan atau bagi penghayat kepercayaan tidak diisi, tetapi tetap dilayani dan dicatat dalam database Kependudukan". Dengan penghapusan pasal ini sesungguhnya Mahkamah Konstitusi hendak menghilangkan dikotomi (atau pembedaan) antara agama yang diakui berdasarkan peraturan perundang-undangan (agama resmi), dengan agama yang tidak diakui serta penghayat kepercayaan yang nomenklaturnya disebutkan dalam Undang Undang Administrasi Kependudukan. Dikotomi/pembedaan selama ini merupakan salah satu penyebab utama diskriminasi tehadap penghayat kepercayaan.

\subsubsection{Pengakuan Dalam Peraturan Turunan Putusan MK Nomor 97/PUU-XIV/2016}

Implikasi Pasca Putusan Mahkamah Konstitusi Nomor 97/PUU-XIV/2016 tentang Administrasi Kependudukan terhadap kedudukan penghayat kepercayaan ditandai dengan keluarkannya kebijakan Pemerintah, sebagai berikut:

1. Peraturan Menteri Dalam Negeri Republik Indonesia (Permendagri) Nomor 118/2017 Putusan Mahkamah Konstitusi Nomor 97/PUU-XIV/2016 ditindaklanjuti oleh Kementerian Dalam Negeri menerbitkan Peraturan Menteri Dalam Negeri Nomor 118 Tahun 2017 Tentang Blangko Kartu Keluarga, Register dan Kutipan Akta Pencatatan Sipil (Permendagri No.118/2017) yang ditetapkan 5 Desember 2017 dan diundangkan tanggal 11 Desember 2017. Peraturan Menteri Dalam Negeri tersebut terdiri dari Bab tentang Blangko Kartu Keluarga, Blangko Register Akta Pencatatan Sipil, Blangko Kutipan Akta Pencatatan Sipil, Penerbitan Kembali Register dan Kutipan Akta Pencatatan Sipil, Pengadaan Blangko, serta terdapat lampiran tentang Spesifikasi Blangko, Register, dan Kutipan Akta Pencatatan Sipil yang terdiri dari Formulasi Kalimat Kartu Keluarga, Register, Kutipan Akta Kematian, Akta Perkawinan, Akta Perceraian, Akta Pengakuan Anak; Register Akta Kematian, Perkawinan, Perceraian, dan Pengakuan Anak; serta Spesifikasi Blangko Kartu Keluarga, Register dan Kutipan Akta Pencatatan Sipil. Dalam Peraturan tersebut terdapat perubahan bahwa salah satu data atau identitas tersebut tercantum "agama/kepercayaan" dan "pemuka agama/pemuka kepercayaan".

2. Surat Edaran Dirjen Dukcapil Nomor: 471.14/10666/DUKCAPIL.

Surat Edaran ini merupakan tindak lanjut dari Putusan Mahkamah Konstitusi Nomor 97/PUU-XIV/2016 dan Peraturan Mendagri Nomor 118 Tahun 2017. Surat Edaran Direktur Jendral Kependudukan dan Pencatatan Sipil tentang Penerbitan Kartu Keluarga (KK) bagi Penghayat Kepercayaan Terhadap Tuhan Yang Maha Esa, tertanggal 25 Juni 2018 ini memuat 4 (empat) hal, yaitu: (1) langkah yang harus diambil oleh Dinas Kependudukan dan Pencatatan Sipil Kabupaten/Kota, yakni agar segera menerbitkan Kartu Keluarga (KK) dengan langkah-langkah yang telah dijelaskan di Surat Edaran tersebut; (2) cara menerbitkan Kartu Keluarga (KK) bagi Penghayat Kepercayaan terhadap Tuhan Yang Maha Esa baik bagi penghayat kepercayaan yang datanya sudah ada dalam database kependudukan maupun bagi penduduk yang ingin merubah data dari agama ke penghayat kepercayaan atau sebaliknya, persyaratan untuk mengurus hal tersebut lebih lanjutnya diuraikan dalam Surat Edaran; (3) contoh penulisan agama dan kepercayaan pada aplikasi SIAK versi 7.0; serta (4) Pengawasan yang dilakukan oleh Kepala Unit Kerja/Dinas Kependudukan dan Pencatatan Sipil Provinsi terhadap pelaksanaan pelayanan penerbitan Kartu Keluarga (KK) bagi penghayat kepercayaan yang dilakukan oleh Dinas Kependudukan dan Pencatatan Sipil Kabupaten/Kota (Micom, 2018).

\subsubsection{Dampak Hukum Putusan MK Nomor 97/PUU-XIV/2016}

Dengan dihapusnya pasal 61 ayat 2 , sebagaimana telah disebutkan sebelumnya, maka pembedaan antara agama yang diakui dan tidak diakui dinyatakan bertentangan dengan Undang-Undang Dasar 1945. Bagaimana akibat hukum dari penghapusan pasal ini, khususnya terhadap hak untuk memeluk dan menjalankan ibadah bagi pemeluk kepercayaan? Jika melihat pertimbangan hakim Mahkamah Konstitusi, maka hak penghayat kepercayaan untuk memeluk dan menjalankan ibadah dijamin oleh konstitusi (UUD 1945) sama dengan pemeluk agama. Maka seharusnya tidak ada lagi pembedaan antara agama dan penghayat kepercayaan, khususnya terhadap hak memeluk dan 
beribadah. Apalagi jika mengacu Pasal 10 ayat (1) Undang-Undang Nomor 4 Tahun 2014 tentang Penetapan Peraturan Pemerintah Pengganti Undang-Undang Nomor 1 Tahun 2013 tentang Perubahan Kedua Atas Undang-Undang Nomor 24 Tahun 2003 tentang Mahkamah Konstitusi Menjadi Undang-Undang putusan ini termasuk putusan yang langsung memperoleh kekuatan hukum tetap sejak diucapkan dan tidak terdapat upaya hukum yang dapat dilakukan oleh para pihak dan mengikat tidak hanya bagi para pihak tetapi semua orang (erga omnes).

Jaminan lebih lengkap menganai hak memeluk dan menjalankan ibadah bagi pemeluk kepercayaan yang setara dengan agama tertulis jelas dalam bagian pertimbangan hakim. Bagaimana kekuatan hukum pertimbangan hakim dalam putusan ini? Ada dua pendapat mengenai hal ini: Pertama, pertimbangan hukum mengikat. Pendapat ini disampaikan oleh Pter Mahmud Marzuki dan Goodheart, hal ini karena pertimbangan hakim mendasarkan pada fakta materiil dalam pokok perkara. Kedua, pertimbangan hukum mengikat apabila terkait erat dengan amar putusan. Pendapat ini disampaikan oleh Jimly Asshidiqie dan Maruar Siahaan. Apabila tidak terkait langsung dengan amar putusan maka pertimbangan hakim tidak mengikat (Arista, 2019). Jika melihat pertimbangan hakim terkait jaminan hak memeluk dan menjalankan ibadah yang setara antara penghayat kepercayaan dan pemeluk agama, serta penghapusan frasa "agama yang diakui berdasarkan peratuan perundangundangan" terkait erat dengan amar putusan pencabutan pasal 61 ayat 2 UU Adminduk. Hal ini berarti pertimbangan hakim tersebut mengikat sejak putusan dibacakan. Akibat hukumnya, di masa yang akan datang tidak dapat lagi dibentuk sebuah peraturan yang membuat dikotomi antara agama resmi dan tidak resmi, atau antara agama dan kepercayaan.

Selanjutnya, sejak putusan dibacakan, peraturan lain yang menimbulkan akibat pembedaan antara agama dan kepercayaan seharusnya diharmonisasikan atau disesuaikan. Beberapa peraturan tersebut misalnya :1. Undang Undang Nomor 1 PNPS/Tahun 1965 tentang Pencegahan Penyalahgunaan dan/atau Penodaaan Agama (UU PNPS); 2. SK Jaksa Agung No KEP-108/JA/5/1984 tentang pendirian Badan Koodinasi Pengawas Aliran Kepercayaan Masyarakat (BAKOR PAKEM). Keberadaan UU PNPS dan BAKOR PAKEM telah nyata-nyata memberikan pembedaan bagi penghayat kepercayaan, dimana kewenangan BAKOR PAKEM adalah mengawasi keberadaan penghayat kepercayaan. Dalam praktiknya BAKOR PAKEM membubarkan kelompok tertentu. Putusan MK Nomor 97/PUU-XIV/2016 telah mendelegitimiasi politik agama dalam Undang-Undang Administrasi Kependudukan dengan dasar jaminan hak asasi manusia dalam konstitusi (UUD 1945).

Bagaimana cara mengharmonisasikan UU PNPS dengan UU Adminduk (dengan sebagian pasal yang telah dibatalkan MK)? Salah satu cara yang bisa ditempuh adalah dengan legislative review UU Administrasi Kependudukan, dimana dalam legislative review ini selain menghapus pasal-pasal yang telah dibatalkan Mahkamah Konstitusi, sekaligus bisa mencabut Undang-Undang terkait yang bertentangan dengan Undang-Undang Tersebut. Dalam legislatf review tersebut, dapat pula sekaligus mencabut UU PNPS. Apabila UU PNPS dicabut, maka secara otomatis SK Jaksa Agung No KEP-108/JA/5/1984 menjadi tidak memiliki kekuatan hukum.

Pertanyaan selanjutnya adalah, bagaimana "mengontrol" banyaknya aliran kepercayaan agar tidak "menodai" agama, sebagaimana ditakutkan kelompok yang menghendaki keberadaan UU PNPS? Dari sudut pandang hak asasi manusia, negara masih bisa masuk dan mengatur hal-hal yang terkait dengan forum eksternum, atau bagaimana cara kelompok beribadah. Namun demikian, batasan pengaturan harus mendasarkan pada keselamatan publik. Maka negara dapat mengatur agar agama dan/atau kepercayaan dalam mengekspresikan keyakinannya tetap memperhatikan kesehatan, keselamatan maupun kesusilaan baik umatnya maupun publik. Demi kondisi harmoni dalam sebuah negara yang beragam, negara bisa mengatur forum eksternum tersebut, namun tetap memperhatikan hak asasi manusia serta hak-hak kelompok minoritas. Artinya dalam pengaturan ini tidak mengorbankan kelompok minoritas tetapi tetap mengutamakan pemenuhan hak-hak mereka.

\section{Diskusi}

Jika melihat perjalanan sejarah Penghayat Kepercayaan dalam mendapatkan pengakuan dari Negara, terjadi dinamika dan pasang surut. Pada tahun 1945 hak mereka dijamin dalam UUD 1945. Namun pemenuhan tersebut kembali surut ketika kepercayaan 
dikeluarkan dari Kementerian Agama dan tidak dikategorikan sebagai Agama. Sejak saat itu diskriminasi bahkan kekerasan terjadi kepada mereka. Jika dilihat dari sudut pandang Hak Asasi Manusia, apa yang terjadi pada penghayat kepercayaan sesungguhnya bentuk pengabaian Negara atas jaminan dan kebebasan beragama dan berkeyakinan. Hal ini terbukti karena prinsip "kebebasan yang tidak dapat dikurangi" telah dilanggar dengan peristiwa pemaksaan sejumlah keperayaan memilih Agama yang dianggap resmi oleh Pemerintah. Selain itu pendekatan politik dan keamanan oleh BAKOR PAKEM tidak sesuai dengan prinsip "kebebasan lembaga dan status legal". Karena BAKOR PAKEM bisa saja membubarkan kelompok kepercayaan tanpa melalui proses persidangan dan pembuktian di Pengadilan. Setelah reformasi penghayat memiliki pengakuan yang lebih kuat dalam Pasal 28 E UUD 1945, ditambah adanya Undang Undang Nomor 23 Tahun 2006 membeikan ruang pada Penghayat untuk bisa mengakses dokumen administrasi kependudukan. Hanya saja dalam Undang-Undang ini sebagian isinya masih mendiskriminasikan penghayat, sehingga diajukanlah uji materi oleh beberapa warga penghayat ke Mahkamah Konstitusi.

Dari sudut pandang Hak Asasi Manusia, hak kebebasan beragama dan kepercayaan merupakan hak yang tidak dapat dikurangi (non derogable rights). Negara memiliki kewajiban penuh untuk menghormati, memenuhi dan melindungi hak tersebut. Apalagi, pemeluk kepercayaan masuk dalam kategori kelompok minoritas, dimana berdasarkan Kovenan Hak Sipil dan Politik negara memberikan afirmasi terhadap kelompok ini. Sejarah penghayat di Indonesia menunjukan bukan afirmasi melainkan diskriminasi yang didapatkan. Tidak dapat terpenuhinya hak beragama berimbas pada tidak terpenuhinya hak-hak lainnya seperti hak atas dokumen administrasi kependudukan, pelayanan kesehatan, pendidikan dan sebagainya.

Namun demikian, dengan perjuangan kelompok penghayat kepercayaan, berangsurangsur mendapatkan pengakuan Negara. Beberapa pengakuan Negara adalah: Diakomodasinya keperayaan dalam KTP serta dokumen administrasi kependudukan lainnya, perkawinan yang dapat dicatatkan, adanya pendidikan bagi penghayat untuk mata pelajaran agama/kepercayaan. Dikabulkannya uji materi di Mahkamah Konstitusi memberikan harapan baru bagi penghayat, terutama putusan ini memperlihatkan komitmen negara untuk melindungi segenap bangsanya termasuk penghayat kepercayaan. Salah satu hal penting yang dicapai saat dikabulkannya uji materi ini adalah adanya pertimbangan hakim yang menghapuskan dikotomi atau pembedaan antara agama dan kepercayaan sebagai wujud pemenuhan hak asasi manusia yang dijamin konstitusi (UUD 1945). Dalam konteks negara hukum, pemenuhan hak asasi manusia menjadi syarat mutlak. Apalagi jika pasal-pasal mengenai hak asasi manusia telah dituangkan dalam konstitusi. Mahkamah Konstitusi telah tepat menghapuskan dikotomi ini, terutama karena adanya dikotomi menjadi salah satu penyebab diskriminasi yang dialami penghayat kepercayaan.

Perjuangan penghayat masih panjang, terutama karena faktanya saat ini penghayat keperayaan masih dibedakan dari Agama. Hal ini terlihat dari instansi yang mengurusi. Penghayat berada bukan dibawah Kementerian Agama, melainkan Kementerian Pendidikan dan Kebudayaan. Padahal, esensinya, penghayat menjalankan hak mereka dalam beragama. Belum lagi Undang-Undang Nomor 1 Tahun 1965 dan SK Jaksa Agung No KEP108/JA/5/1984 tentang pendirian Badan Koodinasi Pengawas Aliran Kepercayaan Masyarakat (BAKOR PAKEM) masih berlaku. Dalam prakteknya di beberapa daerah penghayat juga masih mengalami diskriminasi. Di Brebes misalnya, penghayat Sapta Dharma belum bisa memakamkan mayat di pemakaman umum. Akhirnya mereka memakamkan mayat keluarga di halaman rumah mereka (Lokakarya Penghayat Keperayaan, Yayasan Satunama, 4 Juli 2020). Beberapa komunitas penghayat juga masih dibayang-bayangi trauma tahun 1965, dimana kekerasan terjadi kepada mereka. Hal ini membuat sebagian dari mereka tetap berlindung pada agama (yang sebelumnya dikenal sebagai agama resmi) sambil menjalankan ibadah menurut tata cara penghayat kepercayaan. Walaupun menurut Syamsul Maarif, penghayat yang menjalankan baik agama maupun kepercayaan bukan merupakan hal yang perlu dipertentangkan (Maarif, 2018). Namun demikian, jaminan kebebasan beragama dan berkepercayaan yang telah dijamin dalam UUD 1945 masih harus diperjuangkan oleh penghayat, demi sebuah pengakuan penuh terhadap penghayat kepercayaan. Hal ini akan tercapai jika ditandai dengan tidak adanya pembedaan lagi antara penghayat dan bukan penghayat di segala sisi kehidupan. 


\section{Kesimpulan}

Berdasarkan uraian di atas beberapa kesimpulan yang dapat ditarik adalah sebagai berikut: Pertama, Penghayat Kepercayaan mengalami diskriminasi dan pengakuan yang pasang-surut dari periode ke periode. Jika digambarkan dengan grafik akan terlihat grafik yang naik turun. Pada masa pembentukan UUD 1945 diakui bahwa penghayat kepercayaan memiliki hak yang sama dengan agama untuk beragama dan beribadah. Namun, "grafik" nya menjadi turun dan terus turun ketika muncul berbagai kebijakan yang mendiskriminasi penghayat, bahkan ada periode dimana penghayat mengalami pemaksaan untuk memilih agama resmi. Grafik berangsur-angsur naik setelah reformasi, dimana jaminan berkepercayaan dituangkan dalam Pasal 28E UUD 1945, agak turun setelah diundangkannya Undang-Undang Administrasi Kependudukan dimana dalam UndangUndang tersebut Negara masih membedakan agama resmi dan tidak resmi. "Grafik" berangsur-angsur naik setelah ada putusan dari permohonan yang diajukan penghayat, beberapa dokumen kependudukan bisa dimiliki oleh penghayat, serta pelayanan lainnya. Kedua, Bentuk pengakuan Negara terhadap penghayat kepercayaan dalam Putusan MK Nomor 97/PUU-XIV/2016 adalah dicantumkannya kolom kepercayaan dalam KTP Elektonik yang awalnya (-). Walaupun implementasi Putusan ini juga mendapatkan protes, namun setidaknya keadaan lebih baik bagi penghayat. Setelah putusan MK muncul peraturan turunan yang menjamin penghayat bisa mendapatkan dokumen administrasi kependudukan lain seperti Kartu Keluarga, Kutipan Akta Kematian, Akta Perkawinan, Akta Perceraian, Akta Pengakuan Anak; Register Akta Kematian, Perkawinan, Perceraian, dan Pengakuan Anak yang pada kolom kepercayaan tertulis kepercayaan, bukan (-). Selain pengakuan terkait adminisitrasi kependudukan, melalui putusan ini, Majelis Hakim juga mengakui hak memeluk dan menjalankan ibadah yang setara antara penghayat kepercayaan dan agama. Keberadaan frasa "agama yang diakui berdasarkan peraturan perundang-undangan" telah dinyatakan bertentangan dengan Undang-Undang Dasar 1945. Ketiga, Akibat hukum putusan MK Nomor 97/PUU-XIV/2016 terhadap hak untuk memeluk dan menjalankan ibadah bagi penghayat kepercayaan di Indonesia adalah adanya pengakuan hak memeluk dan menjalankan ibadah yang setara dengan pemeluk agama bagi penghayat kepercayaan. Jaminan ini berakibat di masa yang akan datang, dimana tidak boleh lagi terbit peraturan yang membedakan dan atau mengurangi hak penghayat kepercayaan untuk memeluk dan menjalankan ibadah. Keberadaan putusan ini juga seharusnya mendorong adanya revisi/harmonisasi peraturan lain yang bertentangan dengan putusan ini, misalnya UU No.1 PNPS Tahun 1965 dan SK Jaksa Agung No KEP108/JA/5/1984.

\section{Ucapan Terima Kasih}

Penulis mengucapkan banyak terima kasih kepada pihak yang terlibat dalam penerbitan artikel ini.

\section{Conflicts of Interest}

Penulis menyatakan tidak ada konflik kepentingan pada perjalanan pembuatan artikel ini.

\section{Daftar Pustaka}

Abidin, Z., Rosyid, M., Ersad, Yentriani, A., \& Viri, K. (2019). The First International Conference On Indigenous Religions. The State, Indigenous Religions, and Inclusive Citizenship.

Arista, M. (2019). Kapan Pertimbangan Putusan MK Dikatakan Mengikat dan Tidak Mengikat? Hukumonline.Com.

Bahar, S., Kusuma, A. B., \& Hudawati, N. (1995). Risalah Sidang Badan Penyelidik UsahaUsaha Persiapan Kemerdekaan Indonesia (BPUPKI), Panitia Persiapan Kemerdekaan Indonesia (PPKI), 28 Mei 1945-22 Agustus 1945. Sekretariat Negara Republik Indonesia.

Banu, S. (2018). Majelis Luhur Kepercayaan Terhadap Tuhan Yang Maha Esa Indonesia: Wadah Baru Bagi Para Penghayat Kepercayaan. NewsLab UAJY. http://newslab.uajy.ac.id/2018/12/11/majels-luhut-kepercayaan-terhadap-tuhanyang-maha-esa-indonesia-wadah-baru-bagi-para-penghayat-kepercayaan/

Hidayat, N. (2011). Peradilan Kasus-Kasus Kebebasan Beragama dan Berkeyakinan: Rangkuman 8 Studi Kasus: Dampak, Pencapaian, Hambatan dan Strategi. LBH Jakarta.

Konstitusi. (2017, November). Elemen Data Kependudukan Penghayat Kepercayaan. Majalah Konstitusi, 129, 1-79. 
Lestari, S. (2016). Penghayat Sunda Wiwitan Mengharap Pengakuan Negara. BBC Indonesia. https: / / www.bbc.com/indonesia/majalah-38154420

Maarif, S. (2019). Pasang Surut Rekognisi Agama Leluhur dalam Politik Agama di Indonesia (Revisi, Issue 9). Center for Religious and Cross-cultural Studies.

Mahkamah Konstitusi. (2014). Penghayat Kepercayaan Masuk Kolom Agama dalam KK dan KTP. Mkri.Id. https: / / www.mkri.id/index.php?page=web.Berita\&id=14105

Mahkamah Konstitusi. (2016). Putusan Nomor 97/PUU-XIV/ 2016.

Margiyono, Mutiono, Rumadi, \& Irianto, S. (2010). Bukan Jalan Tengah, Eksaminasi Publik Putusan Mahkamah Konstitusi Perihal Pengujian UndangUndang Nomor 1 PNPS/ 1965 Tentang Pencegahan Penyalahgunaan da/atau Penodaan Agama. The Indonesian Legal Resource Center (ILRC).

Micom. (2018). Kemendagri Terbitkan Panduan Penerbitan KK Bagi Aliran Kepercayaan. Mediaindonesia.Com. https: / / mediaindonesia.com

Nawawi, Lasiyo, \& Wahyono, S. B. (2016). Resistensi Komunitas Bonokeling Terhadap Islam Puritan. Ibda': Jurnal Kebudayaan Islam, 14(1), 90-113.

Penetapan Presiden Republik Indonesia Nomer 1 Tahun 1965 Tentang Pencegahan Penyalahgunaan Dan/ Atau Pedoman Agama.

Undang Undang Dasar Negara Republik Indonesia Tahun1945. https: / / doi.org/10.31227/osf.io/498dh

Undang-Undang Nomor 12 Tahun 2005 tentang Pengesahan International Covenant on Civil and Political Rights.

Undang-Undang Republik Indonesia Nomor 23 Tahun 2006.

Undang-Undang Republik Indonesia Nomor 24 Tahun 2013 Tentang Perubahan Atas UndangUndang Nomor 23 Tahun 2006 Tentang Adminis Kependudukan.

Peraturan Menteri Pendidikan dan Kebudayaan Republik Indonesia Nomor 27 Tahun 2016 Tentang Layanan Pendidikan Kepercayaan Terhadap Tuhan Yang Maha Esa Pada Satuan Pendidikan.

Rumadi, Sihombing, U. P., Yonesta, F., Trisasongko, D., A.M, F., Arianingtyas, R., \& Putra, T. A. (2008). Menggugat BAKOR PAKEM: Kajian Hukum Terhadap Pengawasan Agama Dan Kepercayaan Di Indonesia. The Indonesian Legal Resource Center (ILRC).

Siallagan, H. (2016). Penerapan Prinsip Negara Hukum Di Indonesia. Sosiohumaniora, 18(2), 131-137. https://doi.org/10.24198/sosiohumaniora.v18i2.9947

Sumbulah, U. (2014). Aliran Sesat dan Gerakan Baru Keagamaan (Perspektif UU PNPS No. 1 Tahun 1965 dan Hak Asasi Manusia). Journal de Jure, 6(2), 157-165. https://doi.org/10.18860/j-fsh.v6i2.3209

Tamanaha, B. (2007). A Concise Guide to The Rule of Law. Legal Studies Research Paper Series, 40, 1-20.

Viri, K. (2008). Implementasi Pasal 29 Undang Undang Dasar 1945: Studi Kasus Terhadap Suku Dayak Losarang-Kajian Hak Asasi Manusia. Universitas Atma Jaya Yogyakarta. 